Peer-reviewed scientific periodical, focusing on legal and economic issues of antitrust and regulation.

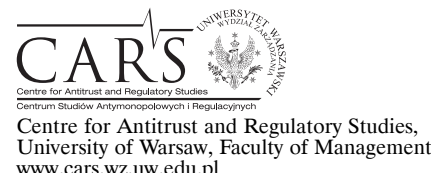

\title{
Accession to the EU's Competition Law Regime: A Law and Governance Approach
}

\author{
by
}

Katalin J. Cseres*

\section{CONTENTS}

I. Introduction

II. Pre-accession rule transposition

1. Competition law in the eastward enlargement

2. Europe Agreements and Stabilisation and Association Agreements

3. The accession governance

III. Post-accession compliance

IV. Regulation $1 / 2003$

1. The governance design of Regulation $1 / 2003$

2. Administrative capacity: the cornerstone of credible enforcement

3. Administrative capacity in Regulation $1 / 2003$

3.1. Silence of Regulation $1 / 2003$ on administrative capacity

3.2. Independence

3.3. Accountability

3.4. Effectiveness of the multi-faceted enforcement system of Regulation $1 / 2003$

V. The ECN: guardian of uniform application of EU law and post-accession compliance

VI. Conclusions

\section{Abstract}

The aim of this paper is to analyse the interplay between the EU's external (pre-accession) and internal (post-accession) governance model in the field of competition law and to reach a deeper understanding of the EU's Europeanization

* Associate Professor of Law, Amsterdam Centre for European Law and Governance, Amsterdam Centre for Law \& Economics, University of Amsterdam; k.j.cseres@uva.nl. 
strategy at the intersection of these two governance models. The paper will critically examine the effectiveness of the internal governance mechanisms of Regulation $1 / 2003$ with regard to the goals of the decentralized enforcement system, as well as with regard to their effectiveness in steering post-accession compliance and Europeanization among the Member States.

Following the Introduction, section II of the paper maps out the EU's external law and governance model that applies vis-à-vis third countries that wish to join the EU. In section III, the paper examines the extent and the manner in which this external model has shaped the EU's internal governance model vis-à-vis its Member States. Section IV analyses Regulation 1/2003 as the main driver behind the effective implementation of EU competition law in the Member States as well as its governance mechanisms as they framed the Europeanization process. In order to evaluate the effectiveness of post-accession compliance, section IV examines the compound procedural framework, composed of EU and national administrative rules, which underlies and challenges the enforcement of EU competition law. Also specifically investigated here is how the administrative capacity of national competition authorities affects competition law enforcement. This inquiry is enriched in section $\mathrm{V}$ with a detailed assessment of the European Competition Network as the EU's main mechanism for the monitoring of Member States' postaccession compliance with EU law.

\section{Résumé}

Le but de cet article est d'analyser l'interaction entre le modèle de gouvernance externe (pré -adhésion) et interne (post-adhésion) de l'UE dans le domaine du droit de la concurrence et d'arriver à une compréhension plus profonde de la stratégie de l'UE sur l'européanisation de l'intersection entre les modèles de gouvernance interne et externe. Larticle examinera l'efficacité des mécanismes de gouvernance interne du règlement $1 / 2003$ en ce qui concerne les objectifs du système de mise en oeuvre décentralisée et en ce qui concerne leur efficacité dans le respect de guider la conformité de post-adhésion et l'européanisation entre les États membres. Par conséquent, la première partie de l'article (qui suit l'«Introduction») décrit le droit externe de l'UE et le modèle de gouvernance qui s'applique aux pays tiers souhaitant d'adhérer à l'UE. Et dans la section III, il examine à quel point et dans quelle manière ce modèle externe a façonné le modèle de gouvernance interne de l'UE vis-à-vis ses États membres. La section IV analyse le règlement 1/2003 comme le moteur principal de la mise en œuvre effective du droit communautaire de la concurrence dans les États membres et de ses mécanismes de gouvernance qui encadraient le processus de l'européanisation. Afin d'évaluer l'efficacité de la conformité de post-adhésion, la section IV examine le cadre procédural composé des règles administratives européennes et nationales qui soumet et conteste l'application du droit communautaire de la concurrence et étudie la façon dont, en particulier, la capacité administrative des autorités nationales de la concurrence affecte l'application du droit de la concurrence. Cette demande est enrichie dans la 
section $\mathrm{V}$ avec une évaluation détaillée du Réseau européen de la concurrence qui est le mécanisme principal de l'UE pour surveiller la conformité des États membres avec la législation de l'UE dans la phase de post-adhésion.

Classifications and key words: competition law; governance; enlargement; Regulation 1/2003; European Competition Network

\section{Introduction}

Competition law has always formed a core pillar of the European integration process and so it was among the crucial EU accession requirements set for the candidate countries. European competition law had thus a significant influence on the way competition laws and institutions were shaped in the candidate countries. In the pre-accession phase, this was due to conditionality. Still, once conditionality ends and candidate countries become Member States, they fall under EU law and its governance ${ }^{1}$ mechanisms. In competition law, this law and governance framework has developed within the framework of Regulation $1 / 2003^{2}$. Pre-accession rule transposition is well documented and closely monitored by the EU in its Regular Reports on the candidate countries. However, the EU's internal governance mechanisms are less visible and have not been examined in the light of its external model, which developed in the course of the EU's eastward enlargement process.

The aim of this paper is to analyse the interplay between the EU's external (pre-accession) and internal (post-accession) governance model in the field of competition law and to reach a deeper understanding of the EU's Europeanization strategy at the intersection of these two models. Moreover, the paper will critically examine the effectiveness of the internal governance mechanisms of Regulation 1/2003. Its effectiveness will be analysed with regard to the goals of achieving uniform and consistent application of EU law through its decentralized enforcement and considering its effectiveness in steering

1 Governance can be understood as a shift from "government" to "governance", a diffusion and fragmentation of governmental arrangements with a decentring of the state; I. Maher, "Regulation and modes of governance in EC competition law; what's new in enforcement?" (2008) 31(6) Fordham International Law Journal 1720; I. Maher, "Competition Law in the International Domain: Networks as a New Form of Governance" (2002) 29(1) Journal of Law and Society 116. In the EU context, governance has to be understood in the multi-level context of EU institutions, Member States and growing participation of private actors.

2 Council Regulation (EC) No. 1/2003 of 16 December 2002 on the implementation of the rules on competition laid down in Articles 81 and 82 EC of the Treaty, OJ L 1, 4.01.2003, p. 1 . 
post-accession compliance and Europeanization among the Member States. A key question to be answered here is whether these internal mechanisms can be characterized as an experimentalist governance model (with recursive learning and revision from the implementation of general goals in various local contexts) or a hierarchical governance model.

Accordingly, section II of the paper discusses the EU's external law and governance model, which applies vis-à-vis third countries that wish to join the EU. In section III it examines to what an extent and how has this external model shaped the EU's internal governance model vis-à-vis its Member States. Section IV analyses Regulation $1 / 2003$ as the main driver behind the effective implementation of EU competition law in the Member States as well as its governance mechanisms that framed the Europeanization process. In order to evaluate the effectiveness of post-accession compliance, section IV examines the compound procedural framework composed of EU and national administrative rules that underlies and challenges the enforcement of EU competition law. Also specifically investigated here is how the administrative capacity of National Competition Authorities (hereafter: NCAs) affects competition law enforcement. This inquiry is enriched in section $\mathrm{V}$ with a detailed assessment of the European Competition Network (hereafter: ECN) acting as the EU's main mechanism for the monitoring of Member States' post-accession compliance with EU law. The paper closes with conclusions.

\section{Pre-accession rule transposition}

\section{Competition law in the eastward enlargement}

The EU's eastward enlargement was bigger, more intrusive and more transformative than its earlier enlargements of the 1990s. Its influence on domestic legal systems was also more comprehensive because the Europeanization process of the candidate countries' legal orders was interacting with market, constitutional and institutional reforms. In the countries that joined the EU in 2004 and 2007, the implementation of European law was exceptional, due to the employed governance method of a top-down rule transfer, and based on strong EU conditionality ${ }^{3}$. While the

${ }^{3}$ Schimmelfennig defines conditionality as a direct mechanism of Europeanization. The EU disseminates its legal rules and governance by setting them as conditions that external actors have to meet in order to obtain candidate/ accession status or other rewards and avoid sanctions. "[C]onditionality is a bargaining strategy of reinforcement by reward, under which the EU provides external incentives for a target government to comply with its conditions"; 
EU's eastward enlargement is generally seen as an important mechanism for Europeanization ${ }^{4}$, the area of competition law might just illustrate this process most acutely.

It was the enlargement process that induced the adoption of an identifiable body of competition law in the candidate countries of Eastern Europe and lead to the continuous alignment of domestic laws with legislative and policy developments in EU competition law. While competition was in fact nonexistent in the Countries of Central and Eastern Europe (hereafter: CEECs) or the Western Balkans, a clear and comprehensive set of competition rules developed in the shadow of their EU accession. As administratively planned market activities and the central allocation of resources gradually made way to free competition and trade, these countries had to build their competition laws from scratch and, more importantly, had to create a competition culture. Competition law and policy played a significant role in their transition process - they proved of great importance in creating a functioning market economy ${ }^{5}$. Competition law supported and stimulated economic changes. Introducing competition law control mechanisms demonstrated the commitment of the candidate countries to market economy, competition advocacy and fair market practices. In the light of their wish to join the EU, Treaty rules seemed to be an obvious reference point. Since 1990, all CEECs and many of the Western Balkans' countries adopted new competition acts and gradually aligned their legislation to that of the EU.

\section{Europe Agreements and Stabilisation and Association Agreements}

The legal, economic and political requirements of the CEECs' accession to the EU were first laid down in the so-called Copenhagen criteria ${ }^{6}$ of the 1993

F. Schimmelfennig, U. Sedelmeier, "Governance by Conditionality: EU Rule Transfer to the Candidate Countries of Central and Eastern Europe" (2004) Journal of European Public Policy 670; F. Schimmelfennig, "EU External Governance and Europeanization Beyond the EU", [in:] D. Levi-Faur (ed.), The Oxford Handbook of Governance, Oxford 2012. It was only with regard to the CEECs that pre-accession conditionality became a regular feature of EU enlargement policy for all candidates; U. Sedelmeier, "Europeanisation in new member and candidate states" (2006) 1(3) Living Rev. Euro. Gov., http://www.livingreviews.org/lreg-2006-3 (28.04.2014).

4 Europeanization is understood as "the reorientation or reshaping of politics in the domestic arena in ways that reflect policies, practices or preferences advanced through the EU system of governance"; I. Bache, A. Jordan, "Europeanization and Domestic Change", [in:] I. Bache, A. Jordan (eds.), The Europeanization of British Politics, Basingstoke 2006, p. 30.

5 K.J. Cseres, "The impact of Regulation 1/2003 in the New Member States" (2010) 6(2) Competition Law Review, p. 145-182.

6 The conditions that candidates must fulfil are specified in a Commission report entitled "Europe and the challenge of enlargement". They were formalized by the Member States at 
Copenhagen European Council. More details were then added in the 1995 White Paper, which was drafted in order to assist the candidate countries in their preparations to meet the requirements of the internal market ${ }^{7}$. The legal and institutional framework of EU accession, and more specifically the legal basis for aligning domestic competition laws with that of the EU, were laid down in various bilateral agreements between the EU and individual candidates from Central and Eastern Europe (in the so-called "Europe Agreements") ${ }^{8}$ and the Western Balkans (Stabilisation and Association Agreements). The EU prescribed therein the legal and institutional requirements that had to be met by the contracting country. These "approximation clauses" compelled a rigorous transposition of the acquis communautaire into domestic laws.

The Europe Agreements and the White Paper contained the core legal and economic conditions of accession. These conditions included the establishment of a functioning market economy, adherence to various political, economic and monetary aims of the European Union, and the capacity to cope with competitive pressure and market forces within the EU. The duties of the candidate countries included, more specifically: transposition of the competition and state aid acquis; effective enforcement of EU competition and state aid rules; as well as strengthening their administrative capacity through well-functioning competition authorities ${ }^{9}$. The Europe Agreements contained a reproduction of Treaty provisions prohibiting restrictive agreements, abuse of a dominant position and state aid ${ }^{10}$. They also contained a clause that required the respective Association Councils to adopt "necessary rules" for the implementation of the above competition provisions by a given deadline ${ }^{11}$. On

the Copenhagen European Council in June 1993, and then expanded upon by the Commission in a Communication called "Agenda 2000", dated 16 July 1997.

7 The so-called White Paper was drafted in order to assist the Eastern European countries in their preparation for accession to the EU. European Commission, White Paper on the Preparation of the associated countries of Central and Eastern Europe for integration into the Internal Market of the Union, COM (95) 163 (hereafter: White Paper COM (95) 163).

${ }^{8}$ Europe Agreements were concluded with Hungary and Poland in December 1991, with Romania, Bulgaria, the Czech Republic and Slovakia in February 1995, with Estonia, Latvia and Lithuania in February 1998 and Slovenia in February 1999. EU had Association Agreements with Malta since 1971 and with Cyprus since 1973.

${ }^{9}$ See e.g. Articles 62 of the Europe Agreement between the European Communities and their Member States, on the one part, and the Republic of Hungary, on the other part; OJ L 347, 31.12.1993, p. 1; see chapter 2 of the White Paper, COM (95) 163.

10 See e.g. Articles 62 of the Europe Agreement between the European Communities and their Member States, of the one part, and the Republic of Hungary, of the other part (hereafter: Hungary EA), OJ L 347, 31.12.1993, p. 1.

11 The Association Councils were bilateral meetings at ministerial level between the EU and the associated countries. This text is based on the wording of Article 67, 68 of the Hungary EA. 
the basis of the Europe Agreements, the CEECs were to approximate their existing and future legislation in specified legal areas, such as competition law.

Similarly to the CEECs that joined in 2004 and 2007, other candidate and potential candidate countries need to fulfil the Copenhagen Criteria. The EU's relations with the countries of the Western Balkan region were shaped in 1997 by the Council that adopted the Conclusions on the principle of conditionality governing the development of the EU's relations with certain countries of south-east Europe ${ }^{12}$. The EU determined therein the political and economic conditions which later became the basis of its policy towards these countries and which have continued to play an active role in the Stabilisation and Association Process ${ }^{13}$ (hereafter: SAP). The SAP policy framework was established by the EU in order to guide candidate countries to their accession. It not only has the aim of stabilizing them and encouraging their swift transition to a market economy, but also promotes regional cooperation and eventual EU membership. The Stabilisation and Association Agreements (hereafter: SAAs) were tailor-made to the specific situation of each partner country ${ }^{14}$. However, the purpose of each agreement is to achieve formal accession to the EU ${ }^{15}$. All SAAs provide similar regimes concerning the approximation of laws. For example, the SAA with Croatia includes a separate title on the approximation of laws, law enforcement and competition rules.

\section{The accession governance}

In the course of the EU's eastward enlargement, the acquis communautaire became a legally binding reference framework for the candidate countries while the approximation of laws was formulated as a strict obligation for

There is a high textual similarity among the Europe Agreements, which makes this argument relevant for the paper. OJ L 438, 31.12.1993, p. 180.

12 General Affairs Council, Conclusions on the principle of conditionality governing the development of the EU's relations with certain countries of south-east Europe. 29 April 1997, Bulletin of the European Union 4-1997, points 1.4.67 and 2.2.1.

13 European Commission, Stabilisation and Association Process, available at http://ec.europa. eu/enlargement/policy/glossary/terms/sap_en.htm (28.04.2014).

14 European Commission, Stabilisation and Association Agreement, available at http:// ec.europa.eu/enlargement/policy/glossary/terms/saa_en.htm (28.04.2014).

15 The European Commission in its Communication to the Council and the European Parliament of 26 May 1999 on the Stabilisation and Association Process for the countries of South-Eastern Europe set out its approach to establishing cooperation between the European Union and Western Balkan States, based on the development of economic and trade relations with the region and within the region. The Stabilisation and Association Process was initiated and Stabilisation and Association Agreements concluded with Albania, Bosnia and Herzegovina, Croatia and the Former Yugoslav Republic of Macedonia. 
the candidates in the texts of their individual agreements. Moreover, "the basic principle (...) that the entire acquis communautaire must be accepted as binding" 16 was accompanied by stressing the "importance (...) of ensuring its effective application through appropriate administrative and judicial structures" 17 .

The new approach resulted from the fact that the 2004 enlargement was characterized by imperfections of conditionality ${ }^{18}$, lacking rigorous implementation monitoring, and not just literal transposition of EU rules. Changes introduced into the EU's governance mechanisms in 2007 and 2013 can be explained by the EU's wish to overcome the above shortcomings. What is now known as "the new approach in the enlargement policy"19 adopts a methodology based on a structured framework of accession negotiations and a stricter pre-accession monitoring than previous enlargement rounds. There are opening and closing chapters ${ }^{20}$, while progress on these issues is monitored by way of setting interim benchmarks, and actual law enforcement is controlled by measuring implementation track records. The aim of the new approach is to strengthen the EU framework of conditionality and improve and maintain credibility of the enlargement process ${ }^{21}$. The next section of the paper will analyse the mechanisms of post-accession compliance in the light of the aforementioned new external governance framework.

16 See judgment of ECJ of 2 October 1997, Case C-259/95, Parliament v. Council, ECR I-5313, para 17; see F. Cafaggi, O. Cherednychenko, M. Cremona, K.J. Cseres, L. Gorywoda, R. Karova, H.W. Micklitz, K. Podstawa, "Europeanization of Private Law in Central and Eastern Europe Countries (CEECs). Preliminary Findings and Research Agenda" (2010) 15 EUI WP LAW 15.

17 Regular monitoring reports from the Commission see at http://ec.europa.eu/enlargement/ countries/strategy-and-progress-report/ (28.04.2014); White Paper, COM (95) 163.

18 G. Pridham, "The EU's Political Conditionality and Post-Accession Tendencies: Comparisons from Slovakia and Latvia" (2008) 46 Journal of Common Market Studies 365-388.

19 The new approach in the EU enlargement policy puts the rule of law and democratic governance at the centre of the enlargement process, which addresses the crucial issues of justice, security and fundamental rights. European Commission, Commission Communication to the European Parliament and Council. Enlargement Strategy and Main Challenges 2012-2013, $\operatorname{COM}(2012) 600$ final, p. 2-4.

20 The negotiations open and close with chapters 23 (judiciary and fundamental rights) and 24 (justice, freedom and security).

${ }_{21}$ Enlargement Strategy and Main Challenges 2012-2013, COM(2012) 600 final, p. 2; see also Editorial comments, "Fundamental Rights and EU membership: Do as I say, not as I do!" (2012) 49 Common Market Law Review 481-488. 


\section{Post-accession compliance}

Post-accession compliance is a critical test for the effectiveness of the EU's external governance mechanisms, but it is equally helpful in this context to analyse its internal governance mechanisms. With respect to competition law, such internal mechanisms have been laid down within the framework of Regulation 1/2003.

As mentioned, the structured approach of the EU's enlargement policy focused on implementation and actual enforcement of the adopted legislation. How does the enforcement-oriented approach affect EU law and governance in the postaccession phase and thus the enforcement of EU law in the existing Member States? The experiences of the 2004 enlargement indicated that EU leverage was most noticeable and direct on the statutory enactments of substantive law. There was a significant difference however between the black letter of the law and its active enforcement. Falkner and Treib found that the new Member States formed "the world of dead letters" among the 27 Member States ${ }^{22}$. The previously endorsed formal rule adoption (during the pre-accession period) has now been replaced by tracking the records of implementation and actual enforcement of the Europeanized rules. This fact restates the question whether the focus of post-accession compliance is also anchored in implementation and enforcement. In other words, does the EU continue to influence actual law enforcement in its Member States and if so, how?

Many scholars have argued that the fact that conditionality, as an external incentive of membership, was the main mechanism of the adoption of EU rules by the candidate countries makes the analysis of post-accession compliance critical $^{23}$. What factors influence and drive Member States to continue, or to reverse the achievements of accession? And how robust is the Europeanization of national competition laws in the post-accession stage?

The EU's "external competition law" 24 (competition law provisions contained in its bilateral agreements) and its conditionality are replaced after

22 This specific "world of compliance" also includes two countries from the "old" Member States and is characterized by politicized transposition processes and systematic application and enforcement problems. Another well-known characteristic is the weakness of civil society; G. Falkner, O. Treib, "Three Worlds of Compliance or Four? The EU-15 Compared to New Member States" (2008) 46 Journal of Common Market Studies 293-313.

${ }^{23}$ G. Falkner, O. Treib, "Three Worlds..."; F. Schimmelfennig, U. Sedelmeier, "Governance..."; A.L. Dimitrova, B. Steunenberg, "Conclusions: the 'end of history' of enlargement or the beginning of a new research agenda?", [in:] A.L. Dimitrova (ed.), Driven to Change: The European Union's Enlargement Viewed from the East, Manchester 2004, p. 179-193.

24 A. Papadopoulus, "External competition law of the EU" (2013) 4 European yearbook of International Economic law 87-108. 
accession by its internal law and the governance model laid down in Regulation $1 / 2003$ and the accompanying Notices ${ }^{25}$. Regulation 1/2003 delegated an active enforcement role to national actors and established a system of close cooperation between the European Commission and national authorities. It contains also clear legal obligations for national enforcement agencies as well as various governance mechanisms, mostly within the framework of the ECN. These mechanisms accommodate a remarkable Europeanization process of competition rules. They have also developed a commonly shared sense of competition policy and culture among the Member States. The following sections will analyze these legal obligations as well as the governance mechanisms of Regulation $1 / 2003$ and its contribution to the effective implementation of EU competition law.

\section{Regulation 1/2003}

\section{The governance design of Regulation $1 / 2003$}

Regulation 1/2003 formed part of the legal requirements imposed on candidate countries for their EU accession. Legal obligations associated with accession exercised considerable political and economic pressure on the candidate countries and exerted the most significant influence on the way competition laws developed in the CEECs. Under Regulation 1/2003, the new procedural framework of EU competition law formulates a number of legal obligations for Member States ${ }^{26}$. Article 3(1) of Regulation 1/2003 imposed not just a possibility, but an obligation on NCAs to apply Articles 101 and 102 TFEU parallel to their national competition rules when the effect on EU trade criterion is fulfilled as well as introduced a strict supremacy standard ${ }^{27}$.

25 European Commission, Commission Notice on cooperation within the Network of Competition Authorities, OJ C 101, 27.04.2004, p. 43.

26 The new procedural framework abolished the notification system and Article 101 became directly applicable in its entirety, thus including Article 101(3). This required the Member States to enforce Articles 101 and 102 TFEU without the need for notification and a prior administrative decision on Article 101(3).

27 Article 3(1) defines the principle of simultaneous application of national law and competition law with the limitation posed in Article 3(2): Member States may not adopt and apply on their territory stricter national competition laws which prohibit agreements, decisions by associations of undertakings or concerted practices which may affect trade between Member States, but which do not restrict competition within the meaning of Article 101(1), or which fulfil the conditions of Article 101(3) or which are covered by a Regulation on the application of Article 101(3). In other words, stricter national competition laws are not as such objectionable, 
Further legal duties stemming from Regulation 1/2003 were imposed on all Member States, laid down in Article 35 in conjunction with Article 5, and concerned the empowerment of NCAs.

Regulation 1/2003 delegated enforcement powers to independent, expert NCAs and the national courts ${ }^{28}$ in order to relieve the Commission of its increasing administrative burden and make enforcement more efficient ${ }^{29}$. This second round of the so-called double delegation process ${ }^{30}$ created a system of parallel competences and simultaneous application of EU and national competition law. On the one hand, this has generated an enforcement gap between the Commission and the Member States. On the other, it established a system of close cooperation between the European Commission and its Member States and stimulated a remarkable process of increased Europeanization of competition law in all Member States.

Until 1 May 2004, EU competition law has existed as a supranational policy. By introducing the new enforcement system of Articles 101 and 102 TFEU, Regulation 1/2003 has, for the first time, legislated a transnational governance framework for EU and national competition laws. The distinction between supranational and transnational refers to the vertical relationship between EU and national laws and to the horizontal dimension among the Member States ${ }^{31}$. Accordingly, as a supranational policy, EU competition law used to function above the level of the Member States, with the Commission clearly being the central authority in charge. It was not only Regulation 1/2003 that this central government has been "de-centred" across

as long as they are not applied to agreements, concerted practices and decisions of associations of undertakings that fall within the jurisdictional scope of EU competition rules, in breach of Article 3(2). The convergence rule contained in paragraph 2, seeks to create a level playing field by providing a single standard of assessment which allows undertakings to design EU-wide business strategies without having to check them against all the relevant national sets of competition rules. European Commission, Commission Staff Working Paper of 29 April 2009 accompanying the Report on the functioning of Regulation 1/2003, SEC [2009] 574 final, para 141, 142, 152. Supremacy of EU competition law over national competition law has been established by Case 14/68 Walt Wlihelm v. Bundeskartellamt [1969] ECR I, but only for cases where an exemption under Article 101(3) has been granted. See also more recently Case C-17/10 Toshiba, judgment of 14 February 2012.

28 Articles 5 and 6 of Regulation 1/2003.

29 W.P.J. Wils, "Ten Years of Regulation 1/2003 - A Retrospective" (2013) 4(4) Journal of European Competition Law \& Practice 293-301

30 D. Coen, M. Thatcher, "Network Governance and Multi-level Delegation: European Networks of Regulatory Agencies" (2008) 28 Journal of Public Policy 49-71.

31 O. Holman, "Trans-national governance without supra-national government: The case of the European Employment Strategy" (2006) 7(1) Perspectives on European Politics and Society 93. 
other actors such as the Member States and private actors in a horizontal dimension $^{32}$.

Accordingly, Regulation 1/2003 brought a radical change to the relationship between EU competition rules and respective national laws and posed a major challenge to the uniform application of EU law. Regulation 1/2003 had the most visible and direct impact on the substantive rules of national competition laws because of its Article $3^{33}$, while similar convergence and harmonization of administrative procedures and institutional designs of competition authorities has not taken place. When NCAs apply Articles 101 and 102 TFEU, they make use of their national procedural rules and impose remedies and sanctions that are available in their respective legal systems. Consequently, the enforcement of EU competition rules has come to rely on the effective administrative enforcement of EU competition rules through national administrative procedures.

This multifaceted enforcement system will be examined below in order to map out how the governance model of Regulation 1/2003 functions and which challenges it raises in practice.

\section{Administrative capacity: the cornerstone of credible enforcement}

The enforcement of EU competition law by national actors became crucial in the compound procedural mechanisms of Regulation 1/2003. The effectiveness of EU law enforcement had been defined in literature by "the degree to which both the formal transposition and the practical application of supranational measures at the national level correspond to the objectives specified in the European legislation" 34 . The main factors of effective competition law enforcement lie in: effective administrative organization, clearly worded national law provisions and the extent to which European

32 See also Holman who argues that "trans-national governance is about control and authority but - unlike 'government' in democratic polities - not necessarily about legitimacy and democratic accountability"; O. Holman, "Trans-national...”, p. 93; see also J. Black "Decentring regulation: understanding the role of regulation and self-regulation in a "post-regulatory world" (2001) 54(1) Current legal problems 103-146.

33 Stakeholders from legal and business communities have largely confirmed that Regulation $1 / 2003$ has positively contributed to the creation of a level playing field, along with the substantive convergence of national laws with EU competition rules. Article 3 of Regulation $1 / 2003$ has directly influenced the substance of national competition rules. Article 3(1) defines the principle of simultaneous application of national law and competition law.

${ }^{34}$ C. Knill, A. Lenschow, "Coping with Europe: the impact of British and German administrations on the implementation of EU environmental policy" (1998) 5(4) Journal of European Public Policy 595. 
rules are successfully transplanted into the existing institutional and regulatory traditions of the Member States ${ }^{35}$.

As mentioned, the three rounds of eastward enlargement have gradually come to focus the EU's enlargement policy on implementation and actual enforcement of the adopted legislation ${ }^{36}$. Institution-building became a critical aspect of law enforcement in the candidate countries seeing as the EU's enlargement policy made boundaries between institutions more distinct ${ }^{37}$. The incorporation of the acquis communautaire made it necessary to intentionally develop law enforcement bodies in the candidate countries. The notion of "administrative capacity" was introduced by the Madrid European Council and later established as an accession requirement by subsequent accession meetings ${ }^{38}$. Bulgaria and Romania's accession confirmed the EU's increased involvement in reinforcing their administrative capacity in order for them to enforce future EU law ${ }^{39}$.

As a result, the obligations placed on candidate countries not only included the transposition of the competition acquis and the effective enforcement of competition and state aid rules, but also strengthening of the administrative capacity of the candidates through well-functioning competition authorities ${ }^{40}$. The White Paper ${ }^{41}$, which was drafted in order to assist the Eastern European countries in their preparation for EU accession, emphasized that "[I]t is

35 O. Treib, "Implementing and complying with EU governance outputs" (2006) 1(1) Living Reviews in European Governance 4-26 available at http://www.livingreviews.org/lreg-2006-1 (28.04.2014).

36 According to Nicolaides, enforcement became a priority area of EU policy with the process of enlargement due to three factors. First, the candidate countries emerged from many years of communism and had to build institutions that were accountable to citizens and functioned in very different environments than in the past. Second, EU integration has progressed and impediments in the internal market were found in the administrative weaknesses and incorrect implementation of EU law. Third, the legal body of the acquis expanded considerably, especially in the area of the internal market, making proper enforcement key to make the single market work; Ph. Nicolaides, "Preparing or accession to the EU: how to establish capacity for effective and credible application of EU rules", [in:] M. Cremona (ed.), The Enlargement of the European Union, Oxford 2004, p. 47-48.

${ }^{37}$ K. Engelbrekt, "The Impact of Enlargement on Institutional Integrity in Central and Eastern Europe" (2009) 10 Perspectives on European Politics and Society 167-180.

38 For example, transposition of the competition acquis required effective enforcement of competition and state aid rules as well as strengthening of the administrative capacity through well-functioning competition authorities. See e.g. Articles 62 of the Hungary EA; OJ L 347, 31.12.1993, p. 1.

39 European Commission, Strategy Paper of the European Commission on progress in the enlargement process, Communication from the Commission, COM (2004) 657 final, p. 10, 14.

40 See e.g. Articles 62 of the Hungary EA; OJ L347, 31.12.1993, p. 1; see White Paper COM (95) 163, chapter 2, p. 8-16.

41 White Paper COM (95) 163, para 2.30 and 4.34 . 
important though to stress that the exercise is not confined to the sole adoption of laws and regulations or structure building. There must be a continued effort to ensure enforcement of the policy and to make the policy widely known and accepted by all economic agents involved i.e. by governments, companies and by the workforce. The law must not only exist but it must also be applied and - above all - be expected to be applied. Economic agents must take their decisions under the assumption that the policy will be applied"42.

Moreover, it accentuated the relevance of institution-building by requiring viable rules regarding procedures to ensure effective enforcement and thus the functioning of state aid and competition policy. These rules had to address the powers of the authority charged with the application of competition and state aid rules as well as the rights of the undertakings concerned. The authority had to be endowed with sufficient powers to carry out its tasks efficiently ${ }^{43}$.

At the same time, the European Commission has provided substantial financial and technical assistance to the candidates through the PHARE programme. The Programme was, among other things, meant to strengthen public administration and institutions in order for them to function effectively inside the European Union ${ }^{44}$. Similarly, in the on-going accession process with countries from the Western Balkans ${ }^{45}$, the Commission confirmed that a reform of public administration continues to be a key priority under the political criteria in most of the countries ${ }^{46}$. Simultaneously, the relevance of administrative capacity has grown beyond the EU's enlargement policy, as can be seen from an analysis of Regulation 1/2003. Finally, the European Commission has found ways to influence law enforcement in the Member States, for example through the cooperation mechanisms of the $\mathrm{ECN}^{47}$. The role of administrative capacity in Regulation $1 / 2003$ will be analysed in the

\footnotetext{
42 White Paper COM (95) 163, p. 49, 51.

43 White Paper COM (95) 163, p. 52-53, 55-56, 59.

$44 \mathrm{http} / / /$ europa.eu/legislation_summaries/enlargement/2004_and_2007_enlargement/ e50004_en.htm (15.04.2014).

45 European Commission, Enlargement Strategy and Main Challenges 2012-2013, COM (2012) 600 final.

46 European Commission, Enlargement Strategy and Main Challenges 2012-2013, COM (2012) 600 final, p. 5.

47 This increased awareness of EU law enforcement was most visible in the modernization of EU competition law, where Regulation 1/2003 entered into force in 2004. The improvement of cross-border enforcement laid also at the heart of Regulation 2006/2004 on consumer protection cooperation; Ph. Nicolaides, "Preparing...", p. 47-48; see also A. BakardjievaEngelbrekt, "Public and Private Enforcement of Consumer Law in Central and Eastern Europe: Institutional Choice in the Shadow of EU Enlargement”, [in:] F. Cafaggi, H.W. Micklitz (eds.), New Frontiers of Consumer Protection. The Interplay Between Private and Public Enforcement, Antwerp 2009, p. 91.
} 
subsequent parts of the paper by examining criteria such as: independence, accountability, resources and legal competences.

\section{Administrative capacity in Regulation $1 / 2003$}

\subsection{Silence of Regulation $1 / 2003$ on administrative capacity}

Despite the clear emphasis on administrative capacity in the EU's enlargement policy, questions on the institutional design of NCAs were left open in Regulation 1/2003. Including only some very general rules in this context, it did not predetermine the NCAs' organizational design, systems, structures, processes, and procedures of law enforcement and application, or policy advocacy. At the same time, Regulation 1/2003 contains certain rules on the powers of the NCAs. Article 5 lists their powers when they apply Articles 101 and 102 TFEU by, in fact, listing what type of decisions the NCAs can take in such cases - finding an infringement, ordering interim measures, accepting commitments and imposing fines. The Staff Commission Working Paper accompanying the Report on Regulation 1/2003 admitted that Article 5 is a very basic provision and does not formally regulate or harmonize the procedural rules to be followed by the NCAs or the $\mathrm{ECN}^{48}$. This means that the NCAs apply the same substantive rules, but in divergent procedural frameworks which might also result in the imposition of different sanctions. These procedural differences had been addressed to some extent in Articles 11 and 12 of Regulation 1/2003 with regard to the cooperation of the NCAs within the ECN. Still, Member States have voluntarily converged their procedural rules with those applicable to the European Commission. These procedures apply both to the enforcement of Treaty provisions as well as national competition rules ${ }^{49}$.

Under Article 35 of Regulation 1/2003, each Member State had a clear obligation to designate a competition authority responsible for the application of Articles 101 and 102 TFEU before 1 May 200450. The details have, however, been left to the Member States themselves. The chosen authorities

48 European Commission, Commission Staff Working Paper accompanying the Report on Regulation 1/2003, SEC (2009) 574 final, para 200.

49 ECN's Working Group on cooperation issues and due process monitor this voluntary convergence among the Member States. Individual Reports provide an overview of the different systems and procedures for antitrust investigations within the ECN (31 October 2012); http:// ec.europa.eu/competition/ecn/documents.html (28.04.2014).

50 Article 35(1) of Regulation 1/2003: "The Member States shall designate the competition authority or authorities responsible for the application of Articles 81 and 82 of the Treaty in such a way that the provisions of this regulation are effectively complied with. The measures 
could be administrative or judicial in nature. The only requirement imposed on Member States by Article 35 in this regard was that they have to be designated at all in order to guarantee that the provisions of Regulation $1 / 2003$ are effectively complied with ${ }^{51}$. The accession process merely required an adequate administrative capacity through well-functioning competition authorities. Member States had therefore a great level of freedom in designing the institutional framework of their competition law enforcement systems. Beyond Article 35 of Regulation 1/2003, neither further requirements nor additional formal rules have been formulated on the powers and procedures to be followed by the $\mathrm{NCAs}^{52}$, albeit their competences were very roughly set out in Articles 5 and 6 of Regulation 1/2003.

Hence, Articles 5 and 35 of Regulation 1/2003 imposed very rudimental obligations on the Member States allowing for legal diversity in national procedures and institutional designs. This approach is in line with the general principle of subsidiarity, as enshrined in Article 5 TEU, and respects the Member States' procedural autonomy. The Report on the functioning of Regulation 1/2003 has acknowledged this institutional deficit 53 .

It is not surprising therefore that the diversity of the institutional designs among the competition authorities across the EU is largely determined by country-specific institutional traditions and legacies ${ }^{54}$. Traditionally, new Member States in Central and Eastern Europe gave broad market-regulatory tasks to their regulatory agencies, sometimes with overlapping competences. They have all created a single agency model fulfilling investigative, enforcement

necessary to empower those authorities to apply those Articles shall be taken before 1 May 2004. The authorities designated may include courts".

51 Point 2 of the Notice on cooperation within the NCA provides that "Under general principles of Community law, Member States are under an obligation to set up a sanctioning system providing for sanctions which are effective, proportionate and dissuasive for infringements of EC law". See also judgment of ECJ of 13 September 2005, Case C-176/03, Commission of the European Communities $v$ Council of the European Union, ECR I-7879, paras 46-55.

52 Although national procedural rules had to provide for the admission of the Commission as amicus curiae in national procedures, NCAs will have to be empowered to conduct examinations in accordance with Regulation 1/2003, and Member States will have to report to the Commission. The Commission retains broad supervisory powers that allows it to intervene in proceedings before national authorities and which in fact enables it to act as "primus inter pares". See Article 11(6).

53 European Commission, Commission Staff Working Paper accompanying the Report on Regulation 1/2003, SEC (2009) 574 final, paras 190 and 200.

${ }^{54}$ K. Ost, "From Regulation 1 to Regulation 2: National Enforcement of EU Cartel Prohibition and the Need for Further Convergence" (2014) 5(3) Journal of European Competition Law \& Practice 125-136. 
and adjudicative functions ${ }^{55}$. Most CEECs follow a "non-unitary" structure, where investigative and decision-making activities are separated functionally even though they are handled within one single administrative institution ${ }^{56}$. Some of these authorities, including the Czech and Slovak ones, follow a "unitary" structure and have integrated administrative hierarchies. In other words, they do not have different bodies carrying out different steps of the procedure, even though there may be different divisions (e.g. a competition department and a legal department) inside these authorities that deal with separate aspects of a given case ${ }^{57}$.

Both policy makers and academics have given considerable attention to how the allocation of enforcement powers affects law enforcement ${ }^{58}$. The likely consequences of a certain institutional arrangement for procedural (such as the proportionality of remedies, the time of intervention) and for institutional performance norms (such as expertise, administrative efficiency, independence and accountability) is now subject to various research projects across disciplines ${ }^{59}$. Literature distinguished several factors of effective competition law enforcement. They are measured by: resources and the capacity to carry out their functions, effectiveness of national courts, cooperation within the ECN framework and independence and accountability of the competition agencies. The independence and accountability of NCAs will be analyzed first in the next sections of this paper.

55 Since Croatia has also introduced the competence to issue fines for the competition authority. Previously this was the competence of the courts.

56 The investigation is normally carried out by investigation services and the final decision is adopted by a board/college/council of this administrative institution. Within this structure, there are potentially significant differences in terms of internal organization and relationship between the different bodies. The Reports of the ECN's Working Group on cooperation issues and due process provide an overview of the different systems and procedures for antitrust investigations within the ECN (31 October 2012); http://ec.europa.eu/competition/ecn/decision_ making_powers_report_en.pdf (28.04.2014), p. 6-7.

57 The Reports of the ECN's Working Group on cooperation issues and due process provide an overview of the different systems and procedures for antitrust investigations within the ECN (31 October 2012); http://ec.europa.eu/competition/ecn/decision_making_powers_report_en.pdf (28.04.2014).

58 M.J. Trebilcock, E.M. Iacobucci, "Designing Competition Law Institutions: Values, Structure, and Mandate" (2010) 41 Loyola University Chicago Law Journal 457; E.M. Fox, M.J. Trebilcock, "The Design of Competition Law Institutions and the Global Convergence of Process Norms: The GAL Competition" (2012) 304 NYU Law and Economics Working Papers No. 12-18; H. First, E.M. Fox, D.E. Hemli, "Procedural and Institutional Norms in Antitrust Enforcement: The U.S. System" (2012) NYU Law and Economics Research Paper No. 12-18.

59 C.J. Hanretty, P. Larouche, A.P. Reindl, "Independence, Accountability and Perceived Quality of Regulators", CERRE Report (March 6, 2012). Available at http://www.cerre.eu/sites/ default/files/140210_icer-chronicle.pdf (28.04.2014). 


\subsection{Independence}

EU law has traditionally focused on independence from market players ${ }^{60}$ and it is this very feature that Courts had established as a core element in regulated markets ${ }^{61}$. However, the relevance of political independence has recently increased also to become a fundamental cornerstone of the institutional design of administrative authorities in the EU. While European legislation has become increasingly detailed with respect to the concept of independence, EU judiciary has not formulated any general principles on the independence of regulatory authorities ${ }^{62}$. Accordingly, EU law requires regulators to be independent from political institutions, yet without laying down the criteria of independence that regulatory authorities must meet ${ }^{63}$.

As mentioned, Regulation 1/2003 does not specify any kind of requirements on the formal independence of NCAs. The most recent and comprehensive study on the issue of the formal independence of NCAs is likely in the work of Guidi $^{64}$ who shows extensive variations in independence ${ }^{65}$ among the NCAs. Some of the CEECs (including Hungary, Romania, Bulgaria, Lithuania, Slovenia ${ }^{66}$ and the Czech Republic) score high or relatively high in this regard.

${ }^{60}$ It was already in 1988 , in Directive $88 / 301$ on competition in the markets in telecommunications terminal equipment, that the Commission introduced in Article 6 an obligation on the Member States to entrust the regulation of terminal equipment to a body independent from market parties active in the provision of telecoms services or equipment. This requirement of independence has also been implemented in the second liberalization package in the energy and telecoms sector.

61 See the judgments of ECJ of 19 March 1991, Case C-202/88, France v. Commission, ECR I-1223, paras 51-52; of 13 December 1991, Case C-18/88, RTT v. GB-Inno-BM, ECR I-5973, paras 25-26; of 6 March 2008, Case C-82/07, Comisión del Mercado de las Telecomunicaciones, ECR I-1265.

62 The latest package of liberalization Directives of 2009 mentions a general principle of independence towards the legislative and executive organs. Article 35 of Directive 2009/72 on electricity compels Member States to make the regulatory authority "functionally independent from any other public or private entity" and give it the autonomy to decide "independently of any public body" Article 39 of Directive 2009/73 for gas formulates the same obligation. Directive $2009 / 140$ on electronic communications states that "national regulatory authorities responsible for ex-ante market regulation or for the resolution of disputes between undertakings" (...) "shall act independently and shall not seek or take instructions from any other body in relation to the exercise of these tasks assigned to them under national law implementing Community law".

63 C.J. Hanretty, P. Larouche, A.P. Reindl, "Independence...".

${ }^{64}$ M. Guidi, "Does independence affect regulatory performance? The case of national competition authorities in the European Union" (2011) 64 European University Institute Working Papers; M. Guidi, "Delegation and varieties of capitalism: Explaining the independence of national competition agencies in the European Union" (2014) 12 Comparative European Politics.

65 M. Guidi, "Delegation...”, p. 4.

66 Slovenian Competition protection Agency has been newly established of January 2013 as an independent public body; E. Petrovič Horvat, "Recent legislative developments of the 
The NCA's of others, including Latvia, Slovakia, Poland and Estonia, score low or even very low with respect to their independence ${ }^{67}$. However, Guidi's study raises the question of how does an NCA's de iure independence reflect its de facto independence. Political independence from central government is not guaranteed in all countries, a fact that can be problematic as competition authorities have to use their expertise independently from political and market actors. Syfait ${ }^{68}$ is an important case in this context where the Court of Justice of the EU has gone beyond the analysis of the formal independence of the Greek competition authority. Not only did the Court analyze the NCA's functional independence in detail, it even concluded that the Commission may remove a case from the NCA if the latter is not sufficiently independent ${ }^{69}$. In the light of the aforementioned recent developments of EU law, it can be expected that the independence of NCAs might become subject to more detailed and specific requirements in the future.

\subsection{Accountability}

However, institutional independence cannot be defended without some form of accountability. Public accountability mechanisms for general agency functioning include personnel and budgetary decisions, periodic reviews of the appropriateness of the legislative mandate and agency effectiveness. They have been high on the legal and political agenda not only in the EU, but also in international law and politics ${ }^{70}$. Accountability stands for various mechanisms which involve informing, explaining and justifying conduct ${ }^{71}$. Various forms of accountability can be distinguished such as: accountability to politicians through annual reports, accountability to the market, accountability to stakeholders, especially consumers, accountability to the judiciary, and accountability towards relevant peer groups such as networks of sectoral regulators, or the European Commission.

Accountability to the judiciary through the judicial review of the administrative decisions issued by the NCAs plays a crucial role in overall enforcement of competition law. Judicial review serves as the ultimate control mechanism of the legality of administrative decisions. The intensity

\footnotetext{
Slovenian Competition Law", Slovenian Competition Protection Agency, Visegrad 4 Competition Conference, Budapest 20 March 2014, available at http:/www.gvh.hu//data/cms1026428/1_ panel_5_E_Horvat_Petrovic_presentation.pdf (28.04.2014).

67 M. Guidi, "Delegation..." (2014), p. 4.

68 Case C-53/03 Syfait, judgment of 31 May 2005

69 See C-53/03 Syfait, paras 31-36.

70 M.J. Trebilcock, E.M. Iacobucci, "Designing...”.

71 C.J. Hanretty, P. Larouche, A.P. Reindl, “Independence...”, p. 37.
} 
of the standard of judicial review depends on the specific judicial system. The standard of judicial review continues to be subject to an extensive debate: whether it should be intense, or restrained, especially when it comes to the review of the NCAs' economic analysis of cases ${ }^{72}$. It is argued that more intense judicial control is one of the ways to address the emergence of independent national competition and other regulatory authorities, which often have wide-ranging discretionary powers, in order to counterbalance the lack of political and also administrative accountability ${ }^{73}$. While the cooperation mechanisms within the ECN and with the Commission give a certain degree of administrative accountability control, national judicial review is indispensable with its complementary function of judicial accountability.

Administrative accountability (to stakeholders, to the market, to politicians and towards peer groups) is also growing in relevance. NCAs are evaluated through external and internal audit mechanisms by measuring the effects of their enforcement practice. There is an increasing number of qualitative and quantitative evaluations of their decision-making and law enforcement ${ }^{74}$. Accordingly, if an NCA is to be effective in achieving its objectives, it needs to develop transparent systems for the allocation of resources to priority issues. Beyond annual reports to national parliaments, impact assessments are also growing as are quantitative and qualitative evaluations of the NCAs' law enforcement work.

While competition agencies in new Member States operate today with fairly similar output as their colleagues in older Member States ${ }^{75}$, this was not the case in their initial start-up period. Many of the CEECs had difficulties with enforcing substantive competition rules because enforcement powers were often insufficient to conduct investigations, reach decisions and impose persuasive fines ${ }^{76}$. Being charged with numerous regulatory tasks, many

72 O. Essens, A. Gerbrandy, S. Lavrijssen (eds.), National Courts and the Standard of Review in Competition Law and Economic Regulation, Groningen 2009; K.J. Cseres, J. Langer, "Tetra Laval á la Hongroise", [in:] O. Essens, A. Gerbrandy, S. Lavrijssen (eds.), National Courts and the Standard of Review in Competition Law and Economic Regulation, Groningen 2009, p. $127-144$.

73 S.A.C.M. Lavrijssen, M. de Visser, "Independent Administrative Authorities and the Standard of Judicial Review" (2006) 1 Utrecht Law Review 111-135.

${ }^{74}$ S. Davies, P.L. Ormósi, "A comparative assessment of methodologies used to evaluate competition policy" (2012) 8 Journal of Competition Law and Economics 769-803.

75 Staff Commission Working Paper accompanying the Report on Regulation 1/2003, paras 148-149; http://ec.europa.eu/competition/ecn/statistics.html (28.04.2014), 2. More detailed figures on antitrust cases.

76 OECD, Global Forum on Competition. Questionnaire on the challenges facing young competition authorities. Contribution from Latvia, DAF/COMP/GF/WD(2009)2, p. 3; OECD, Global Forum on Competition. Questionnaire on the challenges facing young competition authorities. Contribution from Poland, DAF/COMP/GF/WD(2009)76, p. 4; OECD, Global 
NCAs devoted much of their time and resources to their wider activities, such as fighting against unfair competition or consumer protection. After the completion of the privatization process and gradual formation of sector regulatory agencies, the NCAs could turn to more traditional competition law enforcement. Still, they often lacked the competence to set priorities or engage in strategic planning and were obliged to follow up on all complaints ${ }^{77}$. For example, competition authorities in Bulgaria, the Czech Republic, Latvia and Romania are bound by the so-called principle of legality, that is, they are obliged to deal with each case that is brought to their attention. The Croatian NCA is a more recent example since it did not have the authority to set its own enforcement priorities before $2009^{78}$.

An increasing number of NCAs can now use priority setting ${ }^{79}$. Administrative entities generally use priority criteria as filters to help them determine which actions are likely to lead to the desired results. For instance, the obligation to deal with a given case is subject to three cumulative conditions in Hungary ${ }^{80}$ while a "public interest" criterion is used in Poland. Similarly to the EU Commission, many NCAs have, however, the possibility to choose which cases they pursue on the basis of what is considered to be a priority in that Member

Forum on Competition. Questionnaire on the challenges facing young competition authorities. Contribution from Bulgaria, DAF/COMP/GF/WD(2009)56, p. 4; OECD, Global Forum on Competition. Questionnaire on the challenges facing young competition authorities. Contribution from Czech Republic, DAF/COMP/GF/WD(2009)6, p. 6; OECD, Global Forum on Competition. Questionnaire on the challenges facing young competition authorities. Contribution from Slovak Republic, DAF/COMP/GF/WD(2009)62, p. 3.

77 OECD, Global Forum on Competition. Challenges faced by young competition authorities. Note by the Secretariat, DAF/COMP/GF (2009)3/REV1, p. 4-5, 13-14.

78 Zakon o zaštiti tržišnog natjecanja, Narodne novine 79/2009, http://narodnenovine. nn.hr/clanci/sluzbeni/2009_07_79_1877.html (28.04.2014). See further A. Svetlicinii, "Abuse of Dominance in South Eastern Europe: Enforcement Practices of the National Competition Authorities in Bosnia \& Herzegovina, Croatia, Macedonia and Serbia" (2012) 8 Mediterranean Competition Bulletin, available at: http://ec.europa.eu/competition/publications/mediterranean/ mcb_8_en.pdf (28.04.2014); M. Kapural, "New kid on the block - Croatia's path to convergence with Ë competition rules" (2014) 5(4) Journal of Competition Law \& Practice 216.

${ }^{79}$ Priority setting is a basic tool of public administrative authorities to rationalize resource allocation and to optimally deal with financial and human resource constraints. Choosing and pursuing articulated priorities with a reasonable and well-explained rationale can enhance the effectiveness as well as the credibility of administrative action; W.E. Kovacic, H.M. Hollman, P. Grant, "How Does Your Competition Agency Measure Up?" (2011) 7(1) European Competition Journal 25-45.

80 These are: (i) the conduct or situation may violate the provisions of the Competition Act, (ii) the competition authority has the power to proceed in the case, and (iii) the proceeding is necessary to safeguard the public interest. 
State $^{81}$. While national practices differ in this respect ${ }^{82}$, a trend of voluntary harmonization is evident that converges towards the Commission's priority setting criteria ${ }^{83}$.

Accountability towards relevant peer groups, such as other NCAs and the EU Commission within the framework of the ECN, play a crucial role in the overall assessment of NCAs also. This form of accountability will be analysed in section $\mathrm{V}$ below.

\subsection{Effectiveness of the multi-faceted enforcement system of Regulation $1 / 2003$}

It has been questioned whether an enforcement system where NCAs, with their diverging capacities and resources that apply different national procedural rules and may thus impose a variety of sanctions and remedies, could jeopardize the effectiveness of EU law, effective judicial protection ${ }^{84}$ and effective law administration. It has also been argued that consistent policy enforcement and the effective functioning of a network requires a certain degree of harmonization of procedures, resources, experiences and independence of the $\mathrm{NCAs}^{85}$. Increasing concern has been expressed about

81 ECN's Working Group on cooperation issues and due process monitor this voluntary convergence among the Member States. Their Reports provide an overview of the different systems and procedures for antitrust investigations within the ECN (31 October 2012); http:// ec.europa.eu/competition/ecn/decision_making_powers_report_en.pdf (28.04.2014).

82 At present, the ability of NCA to set priorities greatly differs among the Member States. ECN Recommendation on the power to set priorities, December 2013, p. 2; available at: http:// www.epant.gr/img/x2/news/news608_1_1386943842.pdf (29.12.2013). See also Working group on Cooperation issues and Due process, Decision-making powers Report, 31 October 2012, p. 71; available at http://ec.europa.eu/competition/ecn/decision_making_powers_report_en.pdf (29.12.2013).

83 In 2012 the ECN's Report on decision-making powers reflected a high level of convergence among the NCAs and was intended to serve as a basis for further harmonization on the NCAs' procedures for competition law enforcement. Working group on Cooperation issues and Due process, Decision-making powers Report, 31 October 2012, p. 5. In 2013, this convergence of national competition law procedures was summarized in the ECN's Recommendations on key investigative and decision-making powers. See in particular the ECN Recommendation on the power to set priorities, p. 3 .

84 The general principle of effective judicial protection, enshrined in Articles 6 and 13 of the ECHR as well as in Article 47 of the Charter of fundamental rights of the European Union and which has now been reaffirmed in Article 19(1) TEU.

85 F. Cengiz, "Regulation 1/2003 Revisited" (2009) TILEC Discussion Paper No. 2009-042 17; C. Gauer, "Does the Effectiveness of the EU Network of Competition Authorities Require a Certain Degree of Harmonisation of National Procedures and Sanctions?", [in:] C.D. Ehlermann, I. Atanasiu (eds.), European Competition Law Annual 2000: The Modernisation of EC Antitrust Policy, Oxford 2001, p. 187-201; F. Jenny, "Does the Effectiveness of the EU Network of Competition Authorities 
the transparency of such a multi-faceted enforcement system and how that affects legal certainty and ultimately the level playing field for undertakings.

National competition law systems deviate on important aspects such as fines, criminal sanctions, liability in groups of undertakings, liability of associations of undertakings, succession of undertakings, prescription periods and the standard of proof, the power to impose structural remedies, as well as the ability of their NCAs to formally set enforcement priorities. These differences may have far-reaching consequences in competition law cases. For example, custodial sanctions may be imposed on cartelists in the United Kingdom or Estonia while in most other Member States it is their firms that are subject to administrative fines ${ }^{86}$.

Recent CJEU judgments, such as Tele 2 Polska $^{87}$ and VEBIC ${ }^{88}$, signal that an in-depth discussion is much needed on the legal puzzles that arise when NCAs apply Articles 101 and 102 TFEU in accordance with domestic procedural rules. As Advocate General Kokott in T-Mobile Netherlands and Others ${ }^{89}$ argued: "[i]n those circumstances, it is of fundamental importance that the uniform application of competition rules in the [European Union] be maintained. Not only the fundamental objective of equal conditions of competition for undertakings on the single market but also the concern for uniform protection of consumer interests in the entire [European Union] would be undermined if in the enforcement of the competition rules of Articles [101 and 102 TFEU] significant disparities occurred between the [NCAs] and courts of the Member States. For that reason, the objective of a uniform application of Articles [101 and 102 TFEU] is a central theme which runs throughout Regulation No 1/2003"90.

Nevertheless, Maher and Ştefan claimed that this bifurcated enforcement system builds flexibility into the relationship between EU and national law and as such is part of the functional success of EU competition law enforcement. They argue that the impact of the new regime on domestic competition laws,

Depend on a Certain Degree of Homogeneity within its Membership?”, [in:] C.D. Ehlermann, I. Atanasiu (eds.), European Competition Law Annual 2000..., p. 208-210.

86 See also K. Ost, "From Regulation 1 to Regulation 2: National Enforcement of EU Cartel Prohibition and the Need For Further Convergence" (2014) 5(3) Journal of European Competition Law \& Practice 125-136.

87 See judgment of CJ of 3 May 2011, Case C-375/09, Prezes Urzędu Ochrony Konkurencji i Konsumentów $v$ Tele2 Polska sp. z o.o., now Netia SA w Warszawie.

88 See judgment of CJ of 7 December 2010, Case C-439/08, Vlaamse federatie van verenigingen van Brood-en Banketbakkers, Ijsbereiders en Chocoladebewerkers (VEBIC) VZW.

${ }^{89}$ See judgment of ECJ of 4 June 2009, Case C-8/08, T-Mobile Netherlands, ECR I-4529, paras 85 and 86.

90 Opinion of Advocate General Kokott delivered on 19 February 2009 in Case C-8/08 (2009) ECR I-4529, p. 85. 
and the wider national legal and political context, is minimized by the fact that neither have procedural rules been harmonized, nor have the requirements been laid down on the nature of the institutional design for competition authorities ${ }^{91}$. This smooth functioning has been regularly confirmed in the Annual Reports of the CEECs ${ }^{92}$. At the same time, the NCAs' ability to apply domestic procedural rules that are well embedded within their national legal systems may increase the effectiveness of their enforcement ${ }^{93}$. This is due to the fact that the NCAs are not completely detached from the domestic legal and political system as they apply national procedural laws and are imbedded in their domestic administrative law institutions.

The way the CEECs adapted and then developed under this mixed enforcement system has not yet been evaluated. Still, a few comments are worth mentioning. Before their EU accession, the CEECs had to implement the competition acquis and Regulation 1/2003 for reasons of EU conditionality - a clear example of top-down legislation through legal transplants ${ }^{94}$. This particular incentive structure and behaviour became subject to a routine through adaptation created during the accession period. As a result, even after accession, the CEECs continued to implement similar procedural rules and soft-law instruments (Notices, Guidelines) as those of the Commission's ${ }^{95}$. Besides routinization, the underlying reason for such behaviour could lie in the belief that once these rules and enforcement methods work effectively and efficiently in the hands of the Commission, they will prove successful in the hands of the NCAs as well.

However, the effectiveness of the transplanted rules was not always confirmed in the different institutional frameworks of the CEECs, where

91 I. Maher, O. Stefan, "Competition Law in Europe: The Challenge of a Network Constitution”, [in:] D. Oliver, T. Prosser, R. Rawlings (eds.), The Regulatory State: Constitutional Implications. Oxford 2010, p. 178-200.

92 See for example Annual reports Hungary 2011-2005 available at www.gvh.hu (28.04.2014).

93 I. Maher, O. Stefan, “Competition Law...”, p. 189.

94 Convergence between different legal rules towards an efficient model may take place as a result of a legal transplant or as an outcome of a competitive process between different legal formants. In the first case, legal transplants are implemented because they proved to be efficient in other legal systems. In the second case, convergence towards efficiency is the result of the interaction between different legal formants. So, while legal transplants are governed by hierarchy, the second scenario is governed by competition among legal formants; U. Mattei, L. Antoniolli, A. Rossato, "Comparative Law and Economics", [in:] B. Bouckaert, G. De Geest (eds.), Encyclopedia of Law and Economics, Cheltenham, UK and Brookfield, US 2000, p. 508-511.

95 See K.J. Cseres, "The impact of Regulation 1/2003 in the New Member States" (2010) 6(2) Competition Law Review 145-182; G. Pridham, "The EU's Political Conditionality and PostAccession Tendencies: Comparisons from Slovakia and Latvia" (2008) 46 Journal of Common Market Studies 365-388. 
agencies often had to divide resources between several legislative competences and, crucially, depended on institutional capacity ${ }^{96}$.

NCAs could not, or did not enforce the transplanted rules due to constraints in their administrative capacity and so these strengthened enforcement tools have not always delivered in the CEECs the expected results. This is, for example, the case with regard to the power to investigate private premises. There are no actual experiences of the use of this investigative tool in the Czech Republic, Estonia, Hungary, Romania, Slovenia and the Slovak Republic. This form of investigation has not been foreseen in the competition rules of Bulgaria at all ${ }^{97}$. A similar experience occurred with regard to leniency programmes which are often praised as the model for procedural convergence and a clear result of the cooperation mechanism within the $\mathrm{ECN}^{98}$. Furthermore, the compound enforcement framework of Regulation 1/2003 raised, in the CEECs, questions on the (parallel) enforcement of national and EU law ${ }^{99}$. Some of these countries even voiced the need for more guidance from the Commission on the decentralized application of Articles 101 and 102 TFEU $^{100}$. These

96 This has been confirmed by the most recent example of Croatia; M. Kapural, "New kid...”, p. 218.

97 Commission Staff Working Paper, para 202; European Commission, Commission Staff Working Paper accompanying the Report on Regulation 1/2003, SEC(2009) 574 final.

98 The first adopted programmes proved to be unproductive due to insufficient transparency or uncertainty about eligibility. Many programmes had been therefore recently revised, they now slowly begin to operate with a few cases in each country. The Czech NCA has applied its leniency program for the first time in 2004 with regard to a cartel agreement in the energy drinks market. Poland had its first leniency case in a 2006 cartel agreement but had largely revised its 2004 leniency programme in 2009 due to several shortcomings of the previous model. In the Czech Republic, Hungary and Slovakia a marker system exists as well. However, in the Czech Republic the decision to grant a 'marker' lies fully at the discretion of the NCA. See M. Zahradnik, H. Madárová, "Slovakia”, [in:] Global Legal Group, International Comparative Legal Guide to: Cartels \& Leniency 2009, London 2009, p. 214; A. Braun, D. Bicková, "Czech Republic", [in:] Global Legal Group, International..., p. 54; G. Bacher, J. Budai, "Hungary", [in:] Global Legal Group, International..., p. 102. In Hungary, leniency was applied for in a few cartel cases yet only one of them has already been closed by the NCA in 2007 (Vj-81/2006).

99 See Case C-17/10 Toshiba, judgment of 14 February 2012 and Case C-68/12 Protimonopolný úrad Slovenskej republiky (cartel of banks), judgment of 7 February 2013.

100 See Slovakian NCA, Z. Šabová, "Coherent application of the EU Competition Law in Slovakia", Antimonopoly Office of the Slovak Republic, Visegrad 4 Competition Conference, Budapest 20 March 2014; available at: http://www.gvh.hu/en//data/cms1026431/2_panel_3_Z_ Sabova_presentation.pdf (27.04.2014). Pursuant to Article 15 3) of Regulation 1/2003, the European Commission submitted a written observation to the Slovakian Supreme Court. In its amicus intervention, the Commission expressed its opinion on the parallel application of EU and national competition rules and the possibility to impose fines for abuse. The case concerned the application of the concept of economic continuity and the effectiveness of fines in relation thereto. The Commission's statement was consistent with the argumentation of the Slovakian NCA's appeal to the Supreme Court. In its judgment of 31 January 2012, the Slovak Supreme 
voices clearly contradict public views on the success of the decentralized enforcement system ${ }^{101}$ and point to the need for more (re)-centralization, or at least for more central steering, to the decentralized enforcement forums.

Beyond this bifurcated enforcement system, the close cooperation between the NCAs and the Commission within the ECN not only plays a crucial role in the governance framework of Regulation 1/2003 but also significantly affects national enforcement strategies. In the next section, the governance mechanisms of the ECN will be analysed in order to examine how it functions as a framework for post-accession compliance and monitoring.

\section{The ECN: guardian of uniform application of EU law and post-accession compliance}

Once accession to the EU's competition law regime is completed, external incentives and conditionality end their function as governance modes and so the mechanisms within the ECN become crucial. The ECN provides incentives for Member States to comply with EU law in the post-accession period while peer accountability provides ways of conduct monitoring by the Commission as well as among the Member States.

The ECN was created in 2004 in order to ensure uniform and consistent enforcement of Articles 101 and 102 TFEU. Its core mission lies in cooperation, both in the application and enforcement of EU competition policy and in actual enforcement of Articles 101 and 102 TFEU by the NCAs.

Court held that the approach of the appeal court to the issue of fines and their functions was not compatible with the need to ensure effective enforcement of EU competition rules. Available at: http://ec.europa.eu/competition/ecn/brief/03_2013/sk_dot.pdf (27.04.2014) and http://ec.europa. eu/competition/court/antitrust_amicus_curiae.html (27.04.2014).

101 A. Italianer, The ECN, convergence and enforcement of EU competition law: achievements and challenges, 3 October 2014, Vilnius, Lithuania European Competition Day of the Lithuanian Presidency; available at: http://ec.europa.eu/competition/speeches/text/sp2013_08_ en.pdf (27.04.2014); W.P.J. Wils, “Ten Years..."; B. Lasserre, The future of the European Competition Network, Keynote speech, Vth Intertic conference on antitrust policy, 16 May, 2013; available at http://www.autoritedelaconcurrence.fr/doc/intervention_BrunoLasserre ECN_rome_mai13.pdf (27.04.2014); interview of the President of the Bundeskartellamt and the Chairman of the ICN, Andreas Mundt, to Concurrences, Competition Law Journal; "Focus, implementation, inclusiveness - The impact of the ICN", 15.11.2013; available at: http://www.bundeskartellamt.de/SharedDocs/Interviews/EN/Concurrence-ImpactICN_neu. html (27.04.2014); H. Kassim, K. Wright, “The European Competition Network: a European Regulatory Network with a Difference”, Paper presented at ECPR Standing Group on Regulatory Governance, Third Biennial Conference, Dublin, 17-19 June 2010, available at http://regulation.upf.edu/dublin-10-papers/2E3.pdf (31.03.2014). 
The ECN was originally set up to provide regular contacts and consultations on enforcement policy between the Commission and the NCAs ${ }^{102}$. In the meantime, the network has moved beyond its original goals and it functions today as a prominent forum for the Member States to discuss enforcement strategies as well as for mutual learning and information sharing. The two main pillars of the ECN are case allocation and information exchange.

The ECN is a highly juridified network with detailed cooperation mechanisms defined in Regulation 1/2003 and in the Notice on cooperation within the Network of Competition Authorities. Importantly, the ECN did not emerge as an initiative of the Member States, unlike other European regulatory networks ${ }^{103}$, but was centrally designed and established by the Commission. Compared to other European Regulatory Networks, the ECN is characterized by its formalism, meant to safeguard consistent law application, and its quasi-hierarchical structure, with the central position being held by the Commission vis-à-vis the Member States.

While the ECN has been formally set up with a quasi-hierarchical structure and a vertical division of enforcement powers between the Commission and the NCAs, it proved to far more horizontal in practice ${ }^{104}$. It was primarily designed as a policy-enforcement network, and yet it functions as a policymaking network through informal discussions and mutual policy learning among the NCAs. For example, it is clear that the ECN is a platform where visible harmonization efforts are made, such as the ECN Model Leniency Programme ${ }^{105}$, the review process of Article 102 TFEU and sector specific regulations ${ }^{106}$. These two distinct functions (enforcement and policy-making) build on each other through formal and informal information exchange and are mutually supportive. However, it is the ECN's spill-over effect into informal soft-law-making where the most criticism with regard to its transparency and accountability has arisen ${ }^{107}$.

Information sharing can take several forms within the ECN. First, there are the formal obligations (Articles 11(3) and (4) of Regulation 1/2003) for Member States to share information about their investigations and about decisions to be take. They may also share confidential information although

102 Point 1 of the Notice on cooperation within the Network of Competition Authorities.

103 D. Coen, M. Thatcher, "Network Governance...".

104 I. Maher, O. Stefan, “Competition Law...", p. 181.

105 ECN, ECN Model Leniency Programme, 2006, available at: http://ec.europa.eu/ competition/ecn/model_leniency_en.pdf (28.04.2014) and the 2012 revision, available at: http:// ec.europa.eu/competition/ecn/mlp_revised_2012_en.pdf (28.04.2014).

106 Commission Staff Working Paper, paras 248-249.

107 D.M.B. Gerard, "The ECN - network antitrust enforcement in the European Union", [in:] D. Geradin, I. Lianos, Research Handbook on EU Competition Law, Cheltenham 2013, p. 181-227; I. Maher, O. Stefan, “Competition Law...”p. 191; F. Cengiz, "Regulation...”. 
respecting the safeguards associated with fundamental rights (Articles 11 and 12(1)). They may conduct inspections of premises or other fact-finding activities on behalf of another NCA investigating a case (Article 22 (1)). The aforementioned formal cooperation mechanisms make it possible to also exchange informal advice, experiences with regard to market analysis or regulatory processes, enforcement strategies and, ultimately, other "softer" information ${ }^{108}$. For example, in the framework of a sector inquiry, Hungary requested the ECN members to share their experience with the Hungarian NCA $(\mathrm{GVH})$ with regard to the investigated sector ${ }^{109}$. Furthermore, regular meetings and interactions prompt members to create personal contacts and to acquire institutional and cultural information about each other and the Commission. This socialization process is an important aspect of the governance mechanisms within the ECN. It creates a commonly shared vision between ECN members of what competition rules are, what the goals are of competition law enforcement, and how it should be enforced. Members of the network share these common objectives and develop a shared identity ${ }^{110}$.

These formal and informal mechanisms of information exchange are core features of the ECN's governance mechanisms. Both the Report on Regulation 1/2003 as well as independent research ${ }^{111}$ found that the ECN functions in practice as a successful "joint enterprise" between the Member States and the Commission. The ECN has often been characterized as an experimentalist governance model ${ }^{112}$ seeing as it employs new governance modes such as consultations, negotiations and soft-law instruments. It has been argued that there is a certain simplicity and "can-do-ness" 113 in the work of the $\mathrm{ECN}$ and that it has been functioning without any major conflicts or serious political or judicial challenges since its conception ${ }^{114}$. This alleged success

\footnotetext{
108 I. Maher, O. Stefan, “Competition Law...”.

109 GVH, Országgyűlési Beszámoló (Annual Report), 2008, p. 188; available at http://www. gvh.hu//data/cms996954/9460AD08913A3368.pdf (28.04.2014).

110 I. Maher. "Regulation...”, p. 1732; I. Maher, O. Stefan, “Competition Law...”, p. 188.

111 H. Kassim, K. Wright, "The European Competition Network...”; Y. Svetiev "Networked Competition Governance in the EU: Delegation, Decentralization or Experimentalist Architecture?" [in:] C. Sabel, J. Zeitlin (eds.), Experimentalist Governance in the EU, Oxford 2010; D.M.B. Gerard, "The ECN...”, p. 181.

112 It has been argued that the ECN's governance follows the logic of experimentalist governance with recursive learning and revision from implementation of general goals in various local contexts; Y. Svetiev, "Networked Competition Governance...".

113 I. Maher, "Functional and Normative Delegation to Non-Majoritarian Institutions: The Case of the European Competition Network" (2009) 7 Comparative European Politics 427; European Commission Annual Report on competition policy, 2005, available at: http://ec.europa.eu/competition/publications/annual_report/2005/en.pdf (28.04.2014), p. 14, 69.

114 S. Wilks, "Agency Escape: Decentralization or Dominance of the European Commission in the Modernization of Competition Policy?” (2009) 18(3) Governance; F. Cengiz, "Regulation...”.
} 
rests on peer esteem, trust, confidentiality and credibility among the ECN members. A strong epistemic community of lawyers, officials and academics is said to additionally strengthen the work of the ECN and the enforcement of EU competition law ${ }^{115}$. This epistemic community shares the knowledge of competition law, which is highly technical and functional and which is intertwined with economic theory. This community extends beyond national borders and it plays a key role in maintaining procedural and substantive consistency in the EU competition law enforcement ${ }^{116}$.

However, there are also critical voices to be heard that argue that there are important characteristics of hierarchical governance present in the ECN with the use of hard-law ${ }^{117}$. The formal governance framework of the decentralized enforcement system was often interpreted as a model which preserved the Commission's central role in the enforcement framework ${ }^{118}$. Some features of the ECN confirm this proposition such as hierarchical governance tools in the form of directly applicable legislative instruments. The Regulation itself is a hierarchical tool of EU governance. European competition law is legislated through directly applicable Treaty provisions and regulations. As such, EU competition rules directly enter national legal regimes. Other areas of EU economic legislation, such as consumer law or sector specific regulation in the energy or telecommunications field, primarily use directives. In comparison, the body of EU competition law exercises top-down pressure and forms an important incentive to align national competition rules to the provisions of the EU. This feature became even more visible throughout the enlargement rounds of 2004, 2007 and 2013 where the candidate countries had to align their competition law regime to that of the EU in a short process governed by strong EU conditionality. The large body of case-law, traditional application of economic analysis and the active involvement of the epistemic community of competition lawyers all reflect traditional forms of governance ${ }^{119}$.

While the ECN proves to be a useful forum for the CEECs to learn and share legal and practical problems ${ }^{120}$, their participation in the network as equal and

115 F. van Waarden, M. Drahos, "Courts and (epistemic) communities in the convergence of competition policies", (2002) 9(6) Journal of European Public Policy 928-929.

116 I. Maher, "Functional...", p. 425.

117 I. Maher, "Regulation...”, p. 1715, 1724; S. Wilks, "Agency Escape...”; G. Monti, "Independence, interdependence and legitimacy: the EU Commission, National Competition Authorities, and the European Competition Network" Working Paper EUI LAW; 2014/01, available at: http://cadmus.eui.eu/bitstream/handle/1814/29218/LAW_2014_01.pdf?sequence=1 (31.05.2014).

118 S. Wilks, "Agency Escape...”, p. 431.

119 F. van Waarden, M. Drahos, "Courts...”, p. 931-932; I. Maher, "Functional...”, p. 424-425.

120 This statement is made on the basis of content of the annual reports of the CEECs' NCAs between 2005-2012 or 2013 when available, and on the basis of a questionnaire which has been sent out to the NCAs in the ten CEECs, not yet including Croatia. 
active members able to influence decision-making can be questioned on the basis of top-down pressure and the conditionality-driven accession processes. Ongoing research on the participation of the CEECs ${ }^{121}$ in the ECN is burdened by the lack of transparency and the limited juridification of network processes - features that raise fundamental questions of accountability and legitimacy. While in theory national parliaments control their NCAs and the European Parliament calls the Commission to account, these control mechanisms are limited in the ECN. The Commission gives a short, one-and-half pages long account of its work within the ECN in its Annual report ${ }^{122}$. The ECN does not have legal personality and it is not clear to what an extent do the NCAs have to answer at the national level for their involvement in the network ${ }^{123}$.

Maher and Ştefan argue that other types of accountability mechanisms, such as reputation, play a role in the $\mathrm{ECN}^{124}$ as well. There is indeed a certain "peer accountability" present within the network which results from the socialization processes which is further generated by reputation mechanisms such as the OECD country reports, the International Competition Network or even the Global Competition Review rankings ${ }^{125}$. These mechanisms make actual enforcement modalities more visible and may induce competition among the agencies ${ }^{126}$. The ECN thus provides a peer-accountability forum, which functions as a governance mechanism steering post-accession law compliance and Europeanization among the Member States. For example, administrative capacity has not only become a cornerstone of credible enforcement in the EU's enlargement policy ${ }^{127}$, institutional building became a critical aspect of law enforcement in all of the EU Member States as well.

121 This research is conducted by the author based on semi-structured interviews with the NCAs and a questionnaire.

122 European Commission, Report from the Commission. Report on Competition Policy 2012, COM(2013) 257 final; European Commission, Commission Staff Working Document accompanying the document the Report from the Commission on Competition Policy 2012, SWD(2013) 159 final. Furthermore, the procedures of the ECN and its main output in the form of soft law instruments marginalize judicial control by the European courts as confirmed by the GC in Case T-340/03, France Telecom SA v Commission, (2007) ECR II-107, para 83.

123 I. Maher, "Functional...", p. 420.

124 I. Maher, O. Stefan, “Competition Law...”, p. 191-192.

125 I. Maher, "The rule of law and agency: the case of competition policy" (2006) 01 IEP WP 4-5.

126 Within the ECN, e.g., all NCAs' annual reports are published in English on the website of the Commission's DG Competition; http://ec.europa.eu/comm/competition/ecn/annual_reports. html (28.04.2014).

127 The notion of 'administrative capacity' was introduced by the Madrid European Council and later established by subsequent accession meetings as a requirement to accession. See e.g. Articles 62 of the Hungary EA, OJ L 347, 31.12.1993, p. 1.; see chapter 23 of the White Paper COM (95) 163 and see 4.34 and 2.30 of the White Paper. The accessions of Bulgaria and 
Moreover, the ECN helps to exchange ideas on enforcement strategies among its members and it has been key to the introduction of new enforcement methods in new Member States, which are slowly growing into full-fledged members of the network and may even become its innovative drivers. Hungary has clearly managed to do so, having many of its enforcement issues, such as the interplay between damages claims and leniency, compliance programs for SMEs, statutory presumption of damage in damages claims, or setting fining guidelines for unfair commercial practices, receive increased attention through the ECN.

However, while these positive features of the ECN are visible and intentionally highlighted by the Commission and the NCAs, there is also a large part of the ECN's functioning which remains invisible to the outside world leaving fundamental problems of transparency, legitimacy and accountability unanswered $^{128}$. The above analysis of the EU's external governance within its enlargement policy, and in particular its external competition law governance model vis-à-vis the CEECs, implies that EU's internal governance may be tilting towards a hierarchical governance modes.

Research on the ECN has focused so far ${ }^{129}$ on the role of the Commission vis-à-vis the Member States rather than on the Member States as local actors. The research perspective should thus be turned towards the lower levels of the governance model by analyzing its horizontal dimension among the Member States. As mentioned already, research is ongoing meant to reveal and evaluate these invisible ECN mechanisms.

\section{Conclusions}

This paper has analyzed the internal law and governance mechanisms of the EU that guide post-accession compliance and the Europeanization of competition law in the light of the EU's external competition law and

\footnotetext{
Romania confirmed the EU's increased intervention with regard to reinforcing administrative capacity in these countries to enforce future EU law. European Commission, Communication from the Commission, Strategy Paper of the European Commission on progress in the enlargement process, $\operatorname{COM(2004)} 657$ final, p. 10, 14. See also A. Bakardjieva-Engelbrekt, "Public and Private Enforcement of Consumer Law in Central and Eastern Europe: Institutional Choice in the Shadow of EU Enlargement", [in:] F. Cafaggi, H.W. Micklitz (eds.), New Frontiers of Consumer Protection. The Interplay Between Private and Public Enforcement, Antwerp 2009, p. 91. See also Ph. Nicolaides, "Preparing...".

128 See also F. Cengiz, "Regulation...”; G. Monti, "Independence...".

129 H. Kassim, K. Wright, "The European Competition Network...”; Y. Svetiev, "Networked Competition Governance...”; D.M.B. Gerard, “The ECN...”; F. Cengiz, "Regulation...”.
} 
governance model that developed in the course of its eastward enlargement process. With respect to EU competition law, such internal mechanisms have developed within the framework of Regulation 1/2003. These post-accession compliance mechanisms are critical with regard to the effectiveness of both the EU's external governance model in competition law, and its internal enforcement system based on Regulation 1/2003.

More specifically, the paper examined how the EU's external governance has been transformed into and affected its internal governance model during the accession of Central and Eastern European countries (in 2004, 2007 and 2013). The paper found that the approach of tracking implementation records and actual enforcement of Europeanized rules before accession continues even after accession, but in a much less visible and less documented manner. This raises its own legitimacy questions. In EU competition law, it is the finely tuned and compound mechanisms laid down in Regulation 1/2003 that provide possibilities for the EU to monitor and influence actual law enforcement in its Member States. The system established by Regulation 1/2003 delegated an active enforcement role to national courts and competition authorities and thus came to rely on effective administrative enforcement by these national actors.

However, the NCAs have diverging capacities and resources, apply different national procedures and thus may impose a variety of sanctions and remedies. Moreover, they operate with diverse internal organization, structure and resources. Fears have been expressed that this bifurcated system might jeopardize the effectiveness of EU law enforcement, requiring therefore a certain degree of harmonization with respect to procedures, resources, experiences and the level of independence of the NCAs. Yet it has also been argued that it is this very feature that builds flexibility into the relationship between EU and national law and as such is part of the functional success of the governance model in EU competition law enforcement. Finally, some have claimed that the impact of the new regime on domestic competition laws, and the wider national legal and political context, is minimized by the fact that neither have procedural rules been harmonized nor have the requirements been laid down on the nature of the institutional design for competition authorities. Ultimately, the NCAs ability to apply their own national procedural rules, which are well embedded within their domestic legal system, might increase the effectiveness of their enforcement.

However, evaluating this mixed enforcement system (in the light of external competition law governance and its governance mechanisms based on conditionality and top-down legislation through legal transplants) shows that the transplanted and the existing legal rules did not work effectively as a single system in the CEECs. NCAs could not, or did not enforce the transplanted rules because of constraints in their administrative capacity. The "copy-pasted" 
EU enforcement tools have thus not always delivered the expected results in this European region. Furthermore, the (parallel) enforcement of national and EU law in the compound enforcement framework of Regulation 1/2003 has caused some legal uncertainty in the CEECs. It illustrated that more guidance from the Commission is needed on the decentralized application of Articles 101 and 102 TFEU. This analysis thus questions the success of the decentralized enforcement system and calls for a critical review of the system with the possibility for its adjustments.

In addition, the paper revealed that the ECN acts as an important governance mechanism steering post-accession compliance and Europeanization among the Member States. It also facilitates the exchange of ideas and mutual learning on their enforcement strategies. The ECN is an effective and successful governance model due to the unique mixture of the varied elements that it employs, which were not created by a single legislative act but have emerged gradually within the broader political, economic and social context of EU competition law. The basis of the current governance model is a constitutionally anchored field of EU law, which is now also deeply rooted in the economic constitutions of its Member States. The goals of competition law and enforcement are commonly shared objectives of the EU, its Member States as well as of the epistemic community of competition lawyers.

Nevertheless, there is a large part of the functioning of the ECN that remains invisible to the outside world and which leaves the fundamental questions of transparency, legitimacy and accountability unanswered. Again, the analysis of the EU's external governance within its enlargement policy, and in particular its external competition law governance model vis-à-vis the CEECs, suggests that the EU's internal governance cannot be characterized as experimentalist governance, with recursive learning and revision from implementation of general goals in various local context, but resembles more hierarchical governance. At the very least, more research is needed to investigate the lower levels of the governance model and to analyze its horizontal dimension among the Member States in order to reveal and evaluate the currently invisible ECN mechanisms.

\section{Literature}

Bakardjieva-Engelbrekt A., "Public and Private Enforcement of Consumer Law in Central and Eastern Europe: Institutional Choice in the Shadow of EU Enlargement", [in:] Cafaggi F., Micklitz H.W. (eds.), New Frontiers of Consumer Protection. The Interplay Between Private and Public Enforcement, Antwerp 2009.

Bache I., Jordan A., "Europeanization and Domestic Change", [in:] Bache I., Jordan A. (eds.), The Europeanization of British Politics, Basingstoke 2006. 
Bacher G., Budai J., "Hunagry”, [in:] Global Legal Group, International Comparative Legal Guide to: Cartels \& Leniency 2009, London 2009.

Braun A., Bicková D., "Czech Republic", [in:] Global Legal Group, International Comparative Legal Guide to: Cartels \& Leniency 2009, London 2009.

Black J., "Decentring regulation: understanding the role of regulation and self-regulation in a "post-regulatory" world" (2001) 54(1) Current legal problems.

Cafaggi F., Cherednychenko O. and others, "Europeanization of Private Law in Central and Eastern Europe Countries (CEECs:)Preliminary Findings and Research Agenda" (2010) 15 EUI WP LAW.

Cengiz F., "Regulation 1/2003 Revisited" (2009) 42 TILEC Discussion Paper.

Coen D., Thatcher M., "Network Governance and Multi-level Delegation: European Networks of Regulatory Agencies" (2008) 28 Journal of Public Policy.

Cseres K.J., Langer J., “Tetra Laval á la Hongroise”, [in:] Essens O., Gerbrandy A., Lavrijssen S. (eds.), National Courts and the Standard of Review in Competition Law and Economic Regulation, Groningen 2009.

Cseres, K.J., "The impact of Regulation 1/2003 in the New Member States" (2010) 6(2) Competition Law Review.

Davies S., Ormósi P.L, "A comparative assessment of methodologies used to evaluate competition policy" (2012) 8 Journal of Competition Law and Economics.

Dimitrova A.L., Steunenberg B., "Conclusions: the 'end of history' of enlargement or the beginning of a new research agenda?", [in:] Dimitrova A.L. (ed.), Driven to Change: The European Union's Enlargement Viewed from the East, Manchester 2004.

Engelbrekt K., "The Impact of Enlargement on Institutional Integrity in Central and Eastern Europe" (2009) 10 Perspectives on European Politics and Society.

Essens O., Gerbrandy A., Lavrijssen S. (eds.), National Courts and the Standard of Review in Competition Law and Economic Regulation, Groningen 2009.

Falkner G., Treib O., "Three Worlds of Compliance or Four? The EU-15 Compared to New Member States" (2008) 46 Journal of Common Market Studies.

First H., Fox E.M., Hemli D.E., "Procedural and Institutional Norms in Antitrust Enforcement: The U.S. System" (2012) 303 NYU Law and Economics Research Paper No. $12-18$.

Fox E.M., Trebilcock M. J., "The Design of Competition Law Institutions and the Global Convergence of Process Norms: The GAL Competition" (2012) 304 New York University Law and Economics Working Papers No. 12-18.

Gauer C., "Does the Effectiveness of the EU Network of Competition Authorities Require a Certain Degree of Harmonisation of National Procedures and Sanctions?", [in:] Ehlermann C.D., Atanasiu I. (eds.), European Competition Law Annual 2000: The Modernisation of EC Antitrust Policy, Oxford 2001.

Gerard D.M.B., "The ECN - Network Antitrust Enforcement in the European Union", [in:] Geradin D., Lianos I. (eds.), Research Handbook on EU Competition Law, Cheltenham 2013.

Guidi M., "Does independence affect regulatory performance? The case of national competition authorities in the European Union" (2011) 64 European University Institute Working Papers.

Guidi M., "Delegation and varieties of capitalism: Explaining the independence of national competition agencies in the European Union" (2014) 12 Comparative European Politics. 
Holman O., "Trans-national governance without supra-national government: The case of the European Employment Strategy" (2006) 7(1) Perspectives on European Politics and Society.

Hanretty C.J., Larouche P., Reindl A.P., "Independence, Accountability and Perceived Quality of Regulators", CERRE Report (March 6, 2012).

Horvat Petrovič E., "Recent legislative developments of the Slovenian Competition Law", Slovenian Competition Protection Agency, Visegrad 4 Competition Conference, Budapest 20 March 2014.

Jenny F., "Does the Effectiveness of the EU Network of Competition Authorities Depend on a Certain Degree of Homogeneity within its Membership?", [in:] Ehlermann C.D., Atanasiu I. (eds.), European Competition Law Annual 2000: The Modernisation of EC Antitrust Policy, Oxford 2001.

Kapural M., "New kid on the block - Croatia's path to convergence with EU competition rules" (2014) 5(4) Journal of Competition Law \& Practice.

Kassim H., Wright K., "The European Competition Network: a European Regulatory Network with a Difference" (2010) Paper presented at ECPR Standing Group on Regulatory Governance, Third Biennial Conference, Dublin 17-19 June 2010.

Knill C., Lenschow A., "Coping with Europe: the impact of British and German administrations on the implementation of EU environmental policy" (1998) 5(4) Journal of European Public Policy.

Kovacic W.E., Hollman H.M., Grant P. "How Does Your Competition Agency Measure Up?" (2011) 7 European Competition Journal.

Lavrijssen S.A.C.M., Visser M. de, "Independent Administrative Authorities and the Standard of Judicial Review" (2006) 1 Utrecht Law Review.

Maher I., "Competition Law in the International Domain: Networks as a New Form of Governance" (2002) 29(1) Journal of Law and Society.

Maher I., "The rule of law and agency: the case of competition policy" (2006) 06/01 Working Paper International Economics Programme.

Maher I., "Regulation and modes of governance in EC competition law; what's new in enforcement" (2007) 31(6) Fordham International Law Journal.

Maher I., "Functional and Normative Delegation to Non-Majoritarian Institutions: The Case of the European Competition Network" (2009) 7 Comparative European Politics.

Maher I., Stefan O., "Competition Law in Europe: The Challenge of a Network Constitution", [in:] Oliver D., Prosser T., Rawlings R. (eds.), The Regulatory State: Constitutional Implications, Oxford 2010.

Monti, G. "Independence, interdependence and legitimacy: the EU Commission, National Competition Authorities, and the European Competition Network" (2014) Working Paper EUI LAW; 2014/01, available at: http://cadmus.eui.eu/bitstream/ handle/1814/29218/LAW_2014_01.pdf?sequence=1.

Nicolaides Ph., "Preparing or accession to the EU: how to establish capacity for effective and credible application of EU rules", [in:] Cremona M. (ed.), The Enlargement of the European Union. Oxford 2003.

Papadopoulus A., "External competition law of the EU" (2013) 4 European yearbook of International Economic law.

Pridham G., "The EU's Political Conditionality and Post-Accession Tendencies: Comparisons from Slovakia and Latvia" (2008) 46 Journal of Common Market Studies.

VOL. 2014, 7(9) 
Ost K., "From Regulation 1 to Regulation 2: National Enforcement of EU Cartel Prohibition and the Need for Further Convergence" (2014) 5(3) Journal of European Competition Law \& Practice.

Šabová Z., "Coherent application of the EU Competition Law in Slovakia", Antimonopoly Office of the Slovak Republic, Visegrad 4 Competition Conference, Budapest 20 March 2014.

Sedelmeier U., "Europeanisation in new member and candidate states" (2006) 1(3) Living Reviews in European Governance.

Schimmelfennig F, "EU External Governance and Europeanization Beyond the EU", [in:] Levi-Faur D. (ed.), The Oxford Handbook of Governance, Oxford 2012.

Schimmelfennig F., Sedelmeier U., "Governance by Conditionality: EU Rule Transfer to the Candidate Countries of Central and Eastern Europe" (2004) 11/4 Journal of European Public Policy.

Svetiev Y., "Networked Competition Governance in the EU: Delegation, Decentralization or Experimentalist Architecture?", [in:] Sabel C., Zeitlin J. (eds.), Experimentalist Governance in the EU, Oxford 2010.

Svetlicinii A., "Abuse of Dominance in South Eastern Europe: Enforcement Practices of the National Competition Authorities in Bosnia \& Herzegovina, Croatia, Macedonia and Serbia" (2012) 8 Mediterranean Competition Bulletin.

Trebilcock M.J., Iacobucci E.M., "Designing Competition Law Institutions: Values, Structure, and Mandate" (2010) 41 Loyola University Chicago Law Journal.

Treib O., "Implementing and complying with EU governance outputs" (2006) 1(1) Living Reviews in European Governance.

Waarden F. van, Drahos M., "Courts and (epistemic) communities in the convergence of competition policies" (2002) 9(6) Journal of European Public Policy.

Wilks S., "Agency Escape: Decentralization or Dominance of the European Commission in the Modernization of Competition Policy?" (2005) 18(3) Governance.

Wils W.P.J., "Ten Years of Regulation 1/2003-A Retrospective” (2013) 4(4) Journal of European Competition Law \& Practice.

Zahradnik M., Madárová H., "Slovakia”, [in:] Global Legal Group, International Comparative Legal Guide to: Cartels \& Leniency 2009, London 2009. 